DOI: 10.31548/machenergy.2020.01.029-039

UDK 693.546

\title{
RESEARCH WORKING PROCESS SORTING OF MATERIALS AND DYNAMIC PARAMETERS OF VIBRATION SCREEN
}

\author{
B. V. Matsiuk, S. V. Orischenko
}

Kyiv National University of Construction and Architecture. Ukraine.

Speciality of article: 133 - industry engineering.

Corresponding authors: matsiuk@gmail.com

Article history: Received - October 2019, Accepted-January 2020.

Bibl. 21, fig. 12, tabl. 0 .

Abstract. Reasonable preconditions and assumptions
in the study of the working process of sorting construction
material are selected model of the system "vibration
damping roller - sorting material", which adequately
reflects the actual sorting process. The influence factors
of the process of material sorting are studied:
granulometric composition and grain shape of the
fraction, density and moisture content of the raw material,
thickness of the material layer on the screen, the speed of
the grains on the screen. As for the sieve, the following
factors were: the sorting mode and its parameters - the
amplitude and frequency of oscillations, the angle of
inclination of the box, the shape and size of the holes of
the sieve, the size of the surface of the sorting and the
mode of operation of the sieve, which implements these
parameters. It has been found that increasing the length
increases the probability of passing particles through the
screen, increasing the efficiency of the sorting. The
working process of material sorting with successive
movement of material particles in the field of harmonic and subsequently and shock-vibrational action is investigated. The evaluation of the sorting process and the parameters of this process are determined. It is proved that the use of common harmonic and shock modes of motion is effective. It is this hypothesis that is the basis of this study. The reliability of the direction is due to the fact that, when implementing the vibration damping mode of sorting, the force effect on the material particles is significantly increased. As a result, the possibility of selfcleaning of those openings in which material particles are stuck and the increase of efficiency and productivity of the sieve is realized. The design scheme is developed and the equations of the joint motion of the studied system are obtained. The solution of the equations is determined by dimensionless parameters, which serve as criteria for evaluation of the vibration shock mode of sorting. The determinated of changes in boundaries of dimensionless parameters that reflect the steady-state operation of a shock-vibration sieve, implementing an efficient sorting process in a mode that is close to resonant. A map of stability was provided and the vibration shock mode was provided at the main resonance. Experimental researches of efficiency of realization of joint vibration and shock mode of sorting on the newly created installation are carried out. Comparison of the parameters obtained by theoretical and experimental paths confirmed the reliability of the assumptions and assumptions adopted in the study. The algorithm of calculation of the "sieve - material" system is developed, the construction of a vibration damping crane is proposed, the novelty of which is confirmed by a patent for a utility model.

Key words: research, working, process, sorting, material, parameter, vibration screen.

\section{Introduction}

The sieves are widely used in construction, mining, chemical and other industries [1, 3-10]. A typical constructive scheme of the sieve is a mobile box, with a flat working surface installed in it as a screen or a bolter with openings [2, 3].

Generator of the motion of a box, as a rule, can be a mechanical [2] or an electromagnetic drive [6], generating external forces, which are the source of the sieve fluctuations. Most vibrating sieve operate in regression mode. Resonance modes are energetically most effective, however, practically not realized due to their low stability in linear resonance.

This is due to narrow amplitude-frequency characteristic in the resonance zone, since even small changes in the load on the sieve result in it from the resonance mode and, as a result, to a sharp change in the working process parameters set by the technology. In addition to well-known studies on the direction of oscillation with the circular [1] or directed [2] movement of the working body of the sieve, the use of common harmonic and shock modes of motion deserves attention. It is this hypothesis that is the basis of this study of the mechanics of the process of sorting the construction materials on sieves.

Such choice of direction is conditioned by the fact that, when implementing the vibration shock mode of the sorting, the force effect on the material particles is significantly increased As a result, the possibility of selfcleaning of those openings in which material particles are stuck and, as a consequence, increases the efficiency and productivity of the sieve. 


\section{Formulation of problem}

Thus, the problem is the development of a mathematical model of "sieve-material" which adequately reflects the real process of sorting and movement of the system as a whole, as well as the development of constructive solutions of the sieve with the implementation of the joint vibration and shock mode of sorting.

\section{Analysis of recent research results}

In the mathematical description of the motion of the sieve, different approaches are used [1, 3, 12], which is the result of the huge number of constructive solutions of the sieves and their parameters [1-3, 7-10]. This is explained by the obvious fact of the emerging complexity of the process of taking into account the mass of the material in calculating the parameters of the sieve [3], the presence of such a phenomenon as the "debris" of screen sieve openings [2], determination of true productivity [16]. This approach forced researchers and designers to use empirical dependencies for a long time to determine the parameters of the sieve [2], derived from the processing the results of experimental studies. The reliability of such dependencies is valid only in the framework of the parameters and design characteristics of the working process used in the experiments to sorting, use of one or another material, with one or another granulometric composition. With the development of the theory of separation processes in the mining and processing industry [1], the development and creation of new designs of sieve in the construction industry $[3,16$, $17,18]$, there has been a tendency in the development of new calculation models. These models describe the process of sorting on the basis of deterministic and predictive representations and to a certain extent reflect the real picture of the motion of sieve mechanics. One of the directions of the search for a model of adequate representation of the real sorting process is the methods of computer modeling of physical and technological processes based on the concept of discrete representation of a material - the method of particle dynamics (molecular dynamics) and the method of discrete elements [1, 2]. The method of discrete elements is considered as a justification of the method of finite elements. In the simulation of the sorting process, this method defines the initial positions and velocities of the particles, and then calculates the forces acting on each particle. The resulting force value is the source information for the next calculation. Such calculations are carried out throughout the whole process of the sorting process. An example of such a simulation is the graph (Fig. 1) obtained in [19].

In work [19] a package of simulation of the dynamics of motion and mechanical interaction of a large number of particles of the friable medium is proposed, taking into account the interaction with the moving elements of the Bulk Flow Analyst TM classification equipment.

However, a large variety of physical properties, granulometric composition, humidity and other characteristics of the material to be sorted is not taken into account in the quoted works [19] and does not solve the problem of creating a generally accepted mathematical model of "rumbling material".

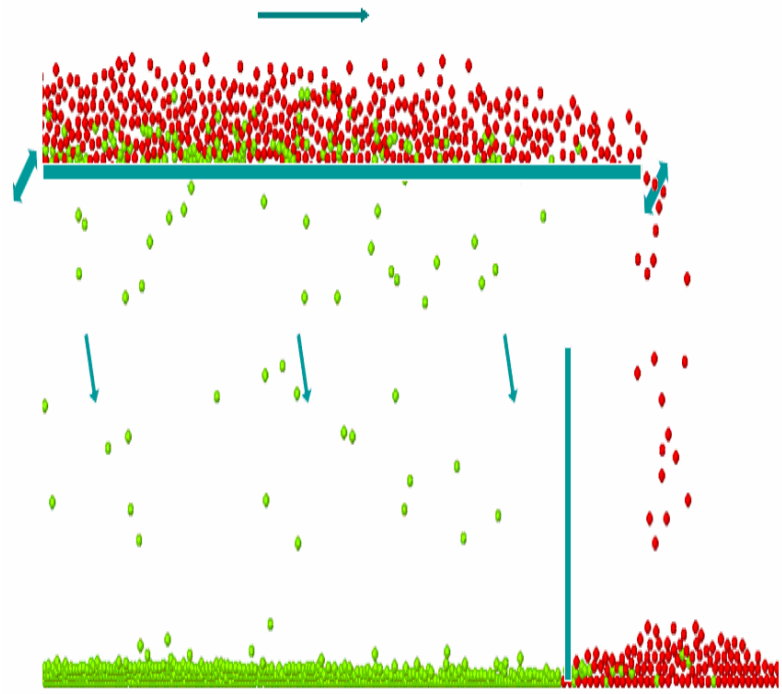

Fig. 1. The simulation painting of a steady sorting mode.

This conclusion is also confirmed by the fact that, besides the above-mentioned characteristics, the size of the screen cell affects the course of the process.

Even the shape of a hole with a round or square gives a significant difference in obtaining the desired product with a given fraction composition.

It is also possible to change the amplitude and frequency of oscillations, which leads to an increase or decrease in the number of contact grains with the surface of the screen.

This can lead to a change in the conditions of selfcleaning the screen from grains that are stuck in the openings, resulting in a change in the efficiency and effectiveness of sifting.

Also, the geometric sizes of the screen significantly affect such indicators as performance, efficiency of sorting, allocation of fine fractions from the source material.

For example, in [20] (Fig. 2), it is noted that increasing the length of the screen increases the probability of passage of material particles through its openings, increasing, mainly, efficiency and only slightly increasing productivity.

According to the author of the work, during the sort there are three characteristic areas of material passing, the formation of which depends on the velocity of particles passing: "In the first region (Fig. 3, I), the smallest the passage rate of the material due to the significant amount of material on the screen and insufficient segregation observed.

In the second region (Fig. 3, II) there is a monolayer of particles and the speed of their passage is maximal.

However, the close placement of particles does not allow them to bounce of the screen. In the third region (Fig. 3, III), the sorting process is characterized by the absence of a monoshale, which leads to a small velocity of the flow of particles through a screen, since they have a disordered motion and the surface of the screen is not used completely "- the end of the quote. 
It is worth noting that such a division into zones is arbitrary, since the process of formation of so-called "areas" is largely determined not only by the parameters of the crash, but also by the parameters of the feeder and does not fully disclose the essence of the process.

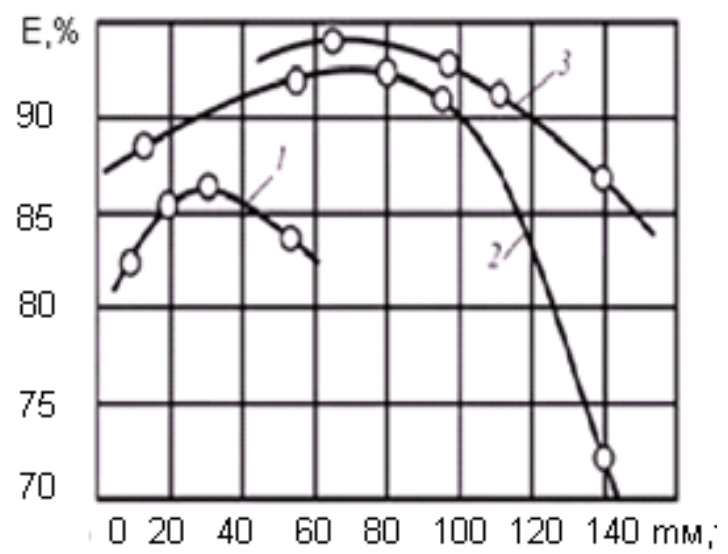

Fig. 2. The dependence of the efficiency of sifting $E$ on the feed material on the sieve $\boldsymbol{m}_{\boldsymbol{M}}$ at a different length and constant width of the screen: $1,2,3$ - the length of the screen, respectively, 800,1600 and $2400 \mathrm{~mm}$. the complexity of the sorting process on the sieve, attention is drawn to the work [21] (Fig. 3).

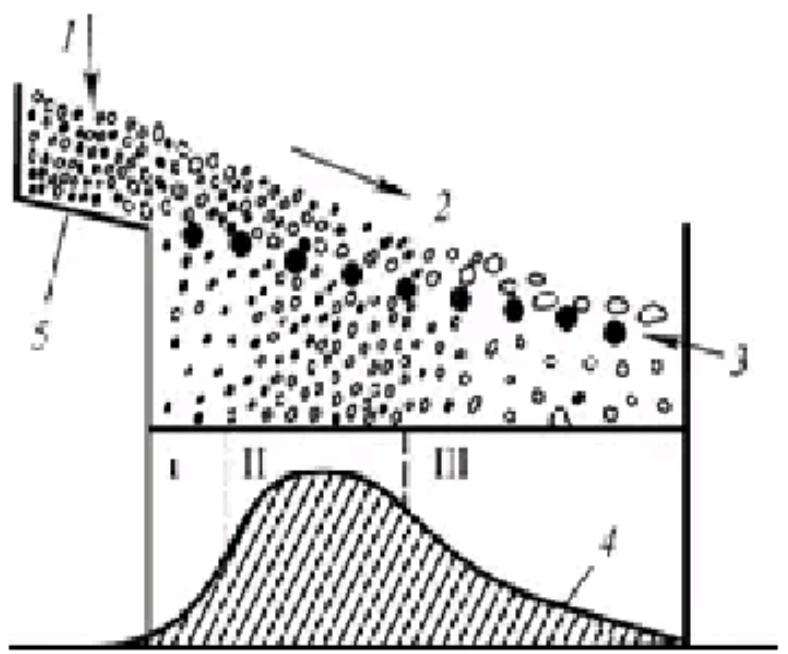

Fig. 3. Areas sorting: 1 - material, 2 - the direction of its movement, 3 - screen, 4 - ready product, 5 - the tray.

\section{Purpose of research}

The order of study the working process of material sorting, we shall consider the progressive movement of the material particle in the field of harmonic and subsequently and shock-vibration for the purpose of evaluation of the process and for the analysis of the working process of the material sorting.

\section{Results of research}

Without taking into account the influence of the neighboring grains and the inequalities of the screen, the motion of the grains with the diameter $d$ (Fig. 4) in a screen with the size of the hole $D$ under the action of the velocity $v$ and gravitational forces can be expressed by the equations:

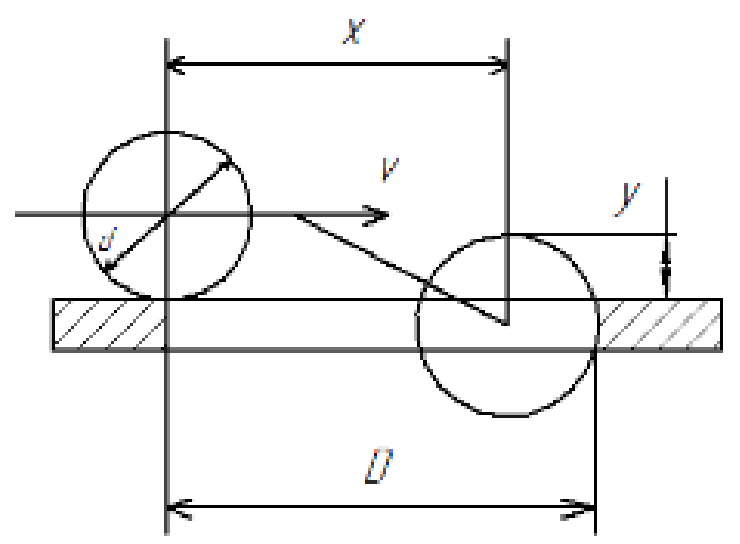

Fig. 4. Scheme of grains of the material on a screen.

$$
y=\frac{g t^{2}}{2} ; x=v t
$$

Since $y=\frac{d}{2}, x=D-\frac{d}{2}$, then, solving the equation (1), we determine the relative velocity of the grains movement by screen:

$$
v=\left(D-\frac{d}{2}\right) \sqrt{\frac{g}{d}} .
$$

In order for the grain to move along the screen, it needs to provide an acceleration that develops the force of inertia that exceeds the forces of resistance. In vibrating sieve with directional oscillations, the working surface carries out harmonic oscillations with the amplitude $X_{0}$ and the frequency $\omega$ by law

$$
x=X_{0} \sin \omega t .
$$

The direction of oscillation forms the angle (Fig. 5):

$$
\beta \angle \frac{\pi}{2} \text {. }
$$

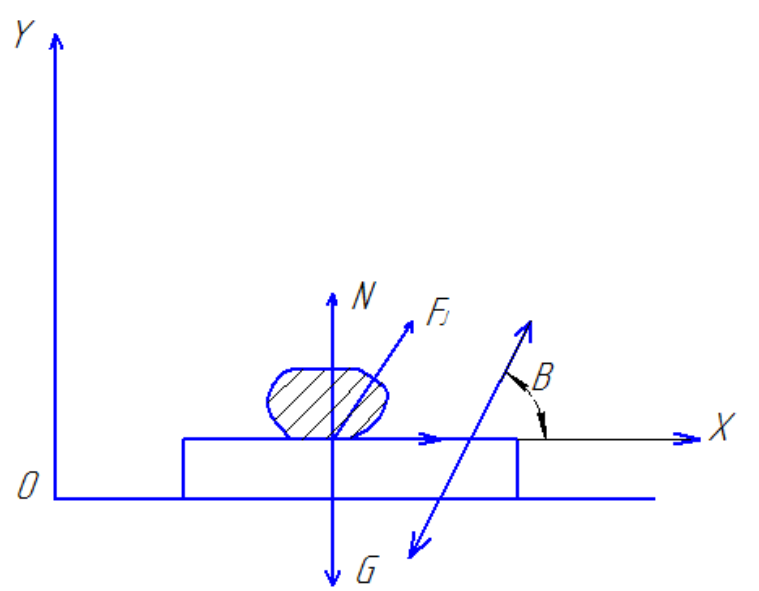

Fig. 5. Pattern of motion a material particle on horizontal surface. 
To determine the motion of the vibrating mass $m$ acting on the plane to mass forces (gravity $\mathrm{G}$, friction $F_{\mathrm{T}}$ and normal reaction $\mathrm{N}$ ) should be added inertia $F_{i}$ equal to the product of mass $\mathrm{m}$ to accelerate the plane $x=-X_{0} \omega^{2} \sin \omega t$ and directed by Angle $\beta$ to the horizontal.

Then the equation of the relative motion of the mass $\mathrm{m}$ of projections on the axes $X O Y$, related to the vibrating surface will look like this:

$$
\begin{aligned}
& m \ddot{x}=m X_{0} \omega^{2} \cos \beta \sin \omega t+F_{m} ; \\
& m \ddot{y}=m X_{0} \omega^{2} \sin \beta \sin \omega t-m g+N,
\end{aligned}
$$

where: $F_{\mathrm{T}}-$ friction, associated with movement of particles in the plane $(y=0)$ of the normal reaction $N$ ratio:

$$
F_{m}=-f N, \ddot{x}>0 ; \quad F=+f N, \ddot{x}<0,
$$

where: $f$ - coefficient of friction sliding..

In this case, the normal reaction can be determined from the second equation (2.4):

$$
N=N(t)=m g-m X_{0} \omega^{2} \sin \beta \sin \omega t .
$$

Moving the material forward in the plane $(x>0)$ is provided on condition:

$$
m X_{0} \omega^{2} \cos \beta \sin \omega t \geq F_{m} .
$$

Taking into account frictional forces $F_{\mathrm{T}}$ and normal reaction we have:

$$
\begin{aligned}
& m X_{0} \omega^{2} \cos \beta \sin \omega t \geq \\
& m g f-m X_{0} \omega^{2} \sin \beta \sin \omega t \sin \beta f,
\end{aligned}
$$

where we determine the angular velocity necessary to move the material forward in a screen:

$$
\omega=\sqrt{\frac{g f}{x_{0} \cos \beta \sin \omega t(1+f)}} .
$$

It is likely that the minimum values of the angular velocity correspond to the position of the vibrational debalance, in which $\omega t=\frac{\pi}{2}$. Then the angular velocity:

$$
\omega_{0}=\sqrt{\frac{g f}{x_{0} \cos \beta(1+f)}} .
$$

To clean the screen from stuck grains and to better separate the material, it is necessary to throw the material over the screen. The flight conditions of particles over a plane follow from equations (4) with

$$
\begin{gathered}
F_{m}=N=0: m \ddot{x}=m X_{0} \omega^{2} \cos \beta \sin \omega t ; \\
m \ddot{y}=m X_{0} \omega^{2} \sin \beta \sin \omega t-m g .
\end{gathered}
$$

Hence the conditions for pouring particles over the screen:

$$
\frac{x_{0} \omega^{2} \sin \beta \sin \omega t}{g} \geq 1 .
$$

Minimum angular velocity required to allow particles to pass over the screen.

$$
\omega=\sqrt{\frac{g}{x_{0} \sin \beta}} .
$$

In inertial sieve with circular oscillations, the direction of inertia is determined by the angle of rotation $\psi=\omega t$ unbalances, and the total value of the inertia force per revolution of the unbalance is zero. Therefore, the surface of the sieve should be sloping so that the additional force $Q=G \sin \alpha$ (Fig. 6).

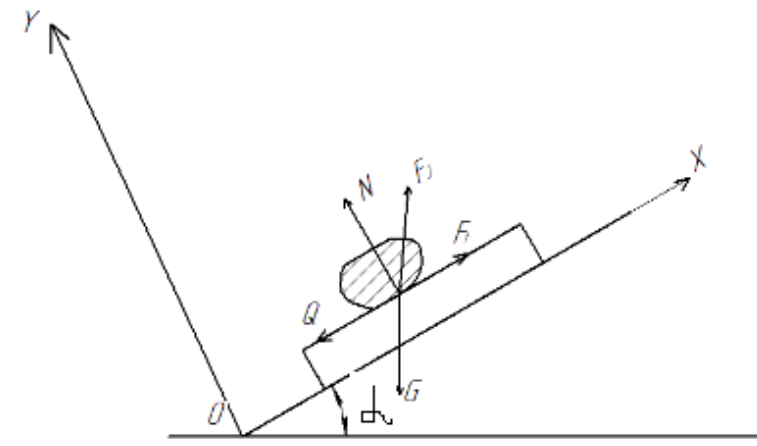

Fig. 6. Scheme of motion of particles on a sloping vibrating surface.

The equation of relative motion of particles in this case will look

$$
\begin{aligned}
& m \ddot{x}=m X_{0} \omega^{2} \cos \beta \sin \omega t+Q \pm f m g \\
& m \ddot{y}=m X_{0} \omega^{2} \sin \beta \sin \omega t-G \cos \alpha+N .
\end{aligned}
$$

For the right part of the first equation (14) the expression for slip friction is already substitute: the upper sign corresponds to sliding forward $(x \succ 0)$, and the lower one - to slip backward $(x \prec 0)$.

The material down the screen will move if the sum of the force $Q$ and the inertia force p exceeds the resistance forces. In this case, the force $Q$ promotes the movement of particles down the screen and prevents their movement in the opposite direction.

The minimum angular velocity required to move the material over the screen and which corresponds to $\varphi=\omega t=0$, are determined from the condition of equation (15):

$$
\omega=\sqrt{\frac{g(f-\sin \alpha)}{x_{0}}} .
$$

The maximum thrusting force will be provided with $\varphi=\omega t=\frac{\pi}{2}$. Consequently, the minimum angular velocity required for particles to pass,

$$
\varphi=\omega t=\frac{\pi}{2}
$$

Now consider the working process of the shockvibration sieve, which can be represented by the resulted calculation scheme (Fig. 7a), in which the bottom frame of the sieve, based on the condition of its vibration isolation (the amplitude of its oscillations is 10 times 
smaller than the amplitude of the sieve), is still, and the box, carrying out oscillations, interacts with the particle material. Such an assumption will allow us to evaluate the parameters of the vibro-impact interaction process of the screen and the material particles, and proceed to the compilation and solution of the equation of motion of the general dynamic system "vibration damping - sorting material".

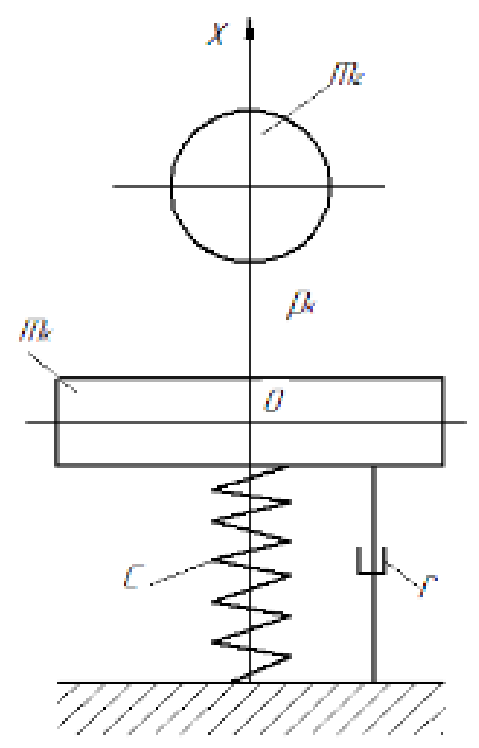

a

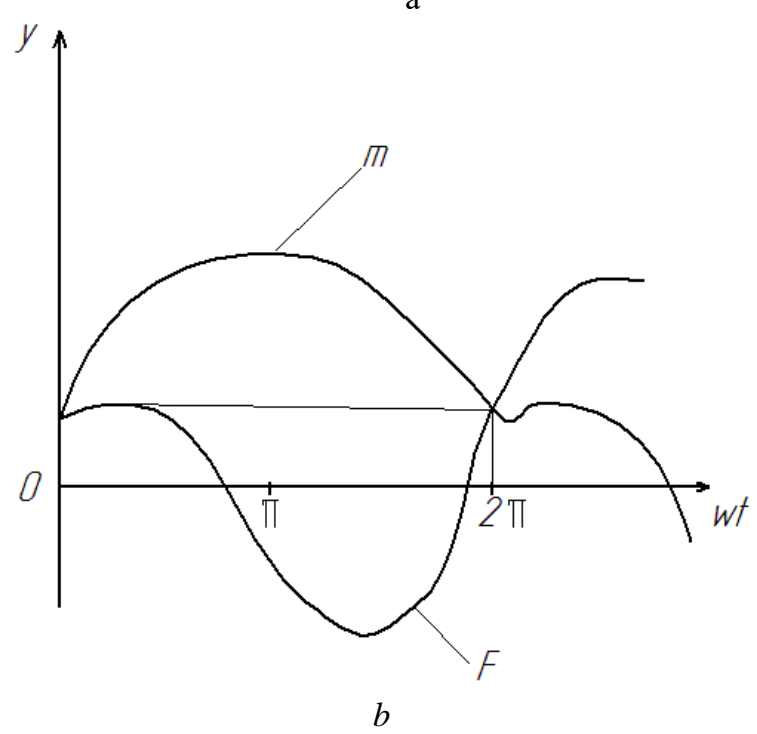

Fig. 7. Scheme of the process of interaction of a material particle with a screen box $a$ and their change of motion $b$.

Under the action of the external action of the excitator, for each period of the fluctuations $\mathrm{T}$ (curve 1 , Fig. 7, b), the mass of the box $M$ and the mass of the particle $m$ are collided, leaving the particle, having received the initial velocity, directed upwards, rises to a certain height $h$ (see Fig. Fig. 7, a), and then by law in the form of a parabola (curve 2, Fig. 7, b) falls on a screen. Since it is assumed that work mode of the system under study is nonlinear (shock - vibration), then to estimate the movement of a material particle in conditions of interaction with the screen of the box, use the known ratio of velocities before and after impact [10]:

$$
R=\left(v_{2}-u_{2}\right) /\left(v_{1}-u_{1}\right),
$$

where $R$ is the rate recovery rate, which represents the ratio of the relative velocity of the box and the sieve after impact, $v_{2}-u_{2}$ to their relative speed before impact. In (1) $v_{1}, v_{2}$ - the speed of the box before and after the impact, $u_{1}, u_{2}-$ the velocity of the particle before and after the impact, respectively. As follows from Fig. 2, b, on the boundary between the collisions of the sieve box and the particle of the material is a fair condition:

by $t=0 ; x_{\hat{e}}=x_{\dot{\leftarrow}}=x_{0}: x_{\hat{e}}=v_{2} ; x_{\dot{\div}}=u_{2}$,

by $T=2 \pi / \omega ; x_{\hat{e}}=x_{\div}=x_{0} ; x_{\hat{e}}=v_{1} x_{\dot{\div}}=u_{1}$

On the interval between the singers, the particle moves according to the law:

$$
x_{\div}=x_{0}+u_{2} t-g t^{2} / 2
$$

To determine the particle velocity before and after the collision with the screen box we use the above boundary conditions (19) and (20) Substituting them into the equation of motion of the particle (21) we obtain the particle velocity to the impact

$$
u_{1}=-\pi g / \omega
$$

The velocity of the screen movement before and after collision with the particle is determined on the basis of the pulse theorem [10]:

$$
\begin{aligned}
& v_{1}=\left[1-R+2 K_{e} R /(1+R)\right] u_{2} \\
& v_{2}=\left[1-R-2 K_{e} R /(1+R)\right] u_{2}
\end{aligned}
$$

where $K_{e}=m_{\imath} / m_{\hat{e}}-$ coefficient of payload which determines the ratio of mass of material, which is on the screen in the process of sorting it to the mass of the box.

The calculation scheme of the vibration damping sieve, taking into account all masses, is a system consisting of two masses (Fig. 8):

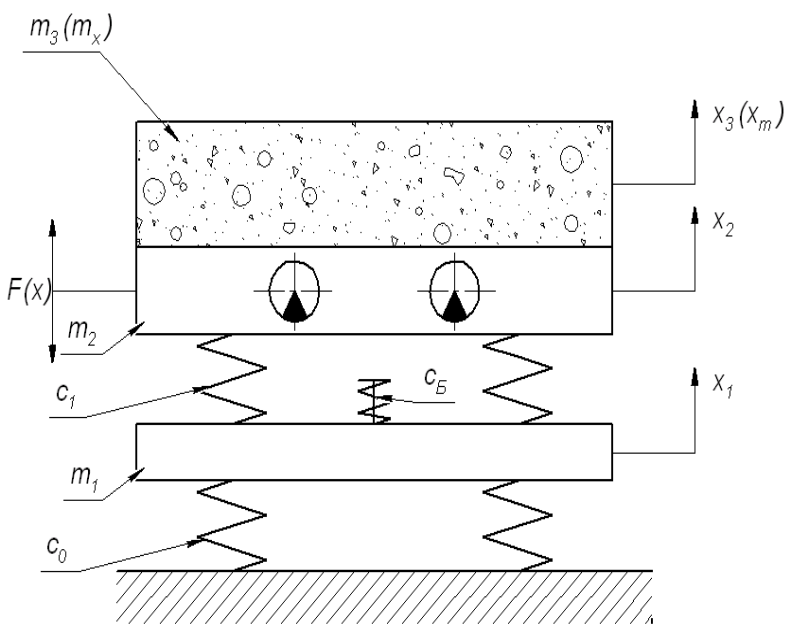

Fig. 8. Scheme of vibration damping system "sieve material", $C_{0}$ - coefficient of elasticity of the lower mass, $C_{l}$ - the coefficient of elasticity between the lower and upper masses, $C_{\sigma}$ - limiter of fluctuations of the upper mass (box). 
Consider the equation of motion of such a system, we find the parameters that make it possible to provide a stable vibration shock mode. To simplify the scheme in the first stage, we assume that the movement of the box and the material is common. Then $x_{2}=x_{3}$, the material mass $m_{3}$ is counted as attached to the mass $m_{2}$. The dissipative component will be taken into account at the final stage of the calculation.

Then the kinetic energy of the system:

$$
T=\frac{1}{2}\left(m_{1} \dot{x}_{1}^{2}+m_{2} \dot{x}_{2}^{2}\right) \text {. }
$$

Potential energy consists of energy of weight $\Pi_{1}$ and energy of elastic forces $\Pi_{2}$.

$$
\Pi_{1}=m_{1} x_{1} g+m_{2} x_{2} g .
$$

We make an expression for the potential energy of elastic forces. We denote $f_{1 \mathrm{~cm}}$ and $f_{2 \mathrm{~cm}}$ the compression of the springs in the position of equilibrium due to the action of weight:

$$
\begin{gathered}
f_{1 c m}=\frac{1}{c_{0}}\left(m_{1}+m_{2}\right) g ; \\
f_{2 c m}=\frac{1}{c_{0}} m_{2} g .
\end{gathered}
$$

We find the compression $f_{1}$ and $f_{2}$ of the springs and with oscillations:

$$
f_{1}=f_{1 c m}-x_{1} ; \quad f_{2}=f_{2 c n}-\left(x_{2}-x_{1}\right) .
$$

Then

$$
\Pi_{2}=\frac{1}{2}\left(c_{0}+f_{1}^{2}+c_{1} f_{2}^{2}\right) .
$$

After simple transformations, we obtain the expression of potential energy:

$$
\Pi=\Pi_{1}+\Pi_{2}=\frac{1}{2}\left(c_{0}+c_{1}\right) x_{1}^{2}-c_{1} x_{1} x_{2}+\frac{1}{2} c_{1} x_{2}^{2} .
$$

Because $\frac{\partial T}{\partial \dot{x}_{i}}=m_{i} \dot{x}_{i}$, a $\frac{d}{d t} \cdot \frac{\partial T}{\partial \dot{x}_{i}}=m_{i} \ddot{x}_{i}$, then, taking into account expressions (23) - (28) we have the equation:

$$
\begin{aligned}
& m_{1} x_{1}+\left(c_{0}+c_{1}\right) x_{1}-c_{1} x_{2}=0, \\
& m_{2} \ddot{x}_{2}+c_{1} x_{2}-c_{1} x_{1}=F_{0} \cos \omega t
\end{aligned}
$$

Equations (29) reflect the movement of the system when the contact between the masses is violated. In the same way we obtain the equations for the joint motion of masses $m_{1}$ i $m_{2}$ :

$$
\begin{aligned}
& m_{1} \ddot{x}_{1}+\left(c_{0}+c_{1}+c\right) x_{1}-c_{1} x_{2}=0, \\
& m x_{2}+\left(c_{1}+c_{2}\right) x_{2}-\left(c_{1}+c\right) x_{1}=F_{0} \cos \omega t
\end{aligned}
$$

The difference between equations (29) i (30) lies in the presence of (30) the boundary $C_{\sigma}$, which is a key parameter that affects the stability of the system fluctuations in the material needed for sorting the material mode by the corresponding fractions.
The resulting system of equations (29), (30) can be somewhat simplified, given that $\left(c_{0}<<c\right)$ and the obvious connection $x=x_{1}+x_{2}$. Taking these conditions and subtracting from the second equation first, we obtain the form of the equation (29), (30), for $\mathrm{x}<0$ (no contact):

$$
\ddot{x}+c_{1}\left(\frac{1}{m_{1}}+\frac{1}{m_{2}}\right) x=\frac{F_{0}}{m_{1}} \cos \omega t
$$

For $\mathrm{x}>0$ (motion in contact):

$$
\ddot{x}+\left(c_{1}+c\right)\left(\frac{1}{m_{1}}+\frac{1}{m_{2}}\right) x=\frac{F_{0}}{m_{1}} \cos \omega t .
$$

The number of variables in the resulting equations (31), (32) can be reduced by applying new dimensionless parameters (time $\tau$ and coordinate $\eta$ ):

$$
\begin{aligned}
& \tau=\omega t ; \eta=\eta_{1}-\eta_{2} ; \alpha=m_{1} / m_{2} \\
& \eta_{1}=\frac{m_{2} x_{1} \omega^{2}}{F_{0}} ; \eta_{2}=\frac{m_{2} x_{2} \omega^{2}}{F_{0}} .
\end{aligned}
$$

Taking into account that $\left(\ddot{x}_{i}\right)_{t}=\omega^{2}\left(\ddot{x}_{i}\right)_{\tau}$ by substituting (33) into (31) and (32) and simple transformations, we obtain a new system of equations:

$$
\begin{aligned}
& \alpha \eta_{1}-\eta_{2}=-\sigma \cos \tau ; \\
& \ddot{\eta}_{2}+\xi_{1} \eta_{2}=-f-\alpha \cos \tau ; \\
& \ddot{\eta}_{2}+\ddot{\xi}_{2} \eta_{2}=-f-\sigma \cos \tau ;
\end{aligned}
$$

In the new system of equations the following relations are taken:

$$
\begin{gathered}
\xi_{1}=\sqrt{\frac{\left(m_{1}+m_{2}\right) c_{1}}{m_{1} m_{2} \omega^{2}},} \\
\xi_{2}=\sqrt{\frac{\left(m_{1}+m_{2}\right)}{m_{1} m_{2}} \frac{\left(c_{1}+c_{2}\right)}{\omega^{2}} .} \\
f=\frac{m_{2} g}{F_{0}}\left(\frac{m_{1}+m_{2}}{m_{2}}\right) .
\end{gathered}
$$

A sign $\sigma$ of the equations (34) takes into account the phase of coercive force.

Parameter $\xi_{1}$ determines the ratio of the Eigen frequency of the fluctuations of the "sieve-material" system in that part of the period when there is no bundle of mass between them to the frequency of forced oscillations $\omega^{2}$.

Parameter $\xi_{2}$ defines the ratio of the Eigen frequency of the fluctuations of the "sieve-material" system in that part of the period when the blow occurred and the masses move together with the frequency of forced oscillations $\omega^{2}$ The parameter $f$ defines the ratio between the given weight and the external force of the oscillator vibrator. Consequently, at given values of the masses of the sieve $m_{1}$ and $m_{2}$, which are to be determined, there is the stiffness of the elastic elements $\mathrm{c}_{1}, \mathrm{c}_{6}$, and $\mathrm{i}$ is the static moment of the mass of the 
disturbances $m_{0} r_{0}$, since the frequency of forced oscillations $\omega$ is usually given by the material sorting technology. In doing so, one must take into account the fact that in addition to finding parameters $\xi_{1}, \xi_{2}$ and $f$ it is needed to know the time of contact mass $\tau$. Obviously, it represents a certain part of the entire period of fluctuations.

Thus, the parameters $\xi, f$, and $\tau$ determine the mode of operation, which is realized under the conditions (31) and (32).

When these conditions are realized, the movement of the masses will be carried out with a separation between them with variable blows between them through the buffer. In this case, the following modes are possible: one-strike, that is, during one period of mass movement, carry one free flight, respectively, one hit on the spring, super harmonious, when during a single period $n$ of change of the forced frequency. There are several strokes, subharmonic when the number of strokes is less than the period of change of the forced frequency. In any case, the sequence of determining the parameters included in (35) and (36) consists of the following operations: the equations of motion of the system are in the segregated and unbroken modes, Then, to reduce the number of parameters, the equations are reduced to dimensionless form and the initial conditions for moving, velocities and time are determined, The given initial conditions are taken into account in the equations of motion and at the final stage the obtained equations of motion of the system in the contact and without contact are equated, which is caused by equal velocity values mass and spring at a time that corresponds to the transition from contact to contactless mass motion. The next step is to determine the change in the limits of parameters that reflect the steadystate operation of the shock-vibration sieve, implementing an efficient sorting process. Since shock-vibration machines operate in a mode that is close to resonance, it is likely that the prediction is that $\xi \geq 1$. Based on the expression for its own oscillation frequency, we can determine the contact time of the masses with the oscillation limiter:

$$
t_{\kappa}=\frac{2 \pi}{\omega_{0}}=2 \pi \sqrt{m / c}
$$

In (37) under the weight $m$ is the reduced mass of the system $m_{1} m_{2} /\left(m_{1}+m_{2}\right)$, and the coefficient of elasticity with the sum $c$ of the coefficients $c_{1}+c_{\hat{a}}$.

Its average values can be taken as, $\tau=\frac{1}{3} T$

where $T$ - is the period of fluctuations of the "sieve material" system.

On the basis of the performed research, a map of stability of the vibration damping mode of the sieve was constructed, which makes it possible to determine the parameters $\xi$ and $f$ for the implementation of specific conditions and sorting mode (Fig. 9).

For the purpose of conducting experimental experiments, an installation (Fig. 10) was developed and made, which was a vibrating sieve with the ability to change the screen, adjust amplitude and frequency of oscillations in wide bands $[17,18]$.

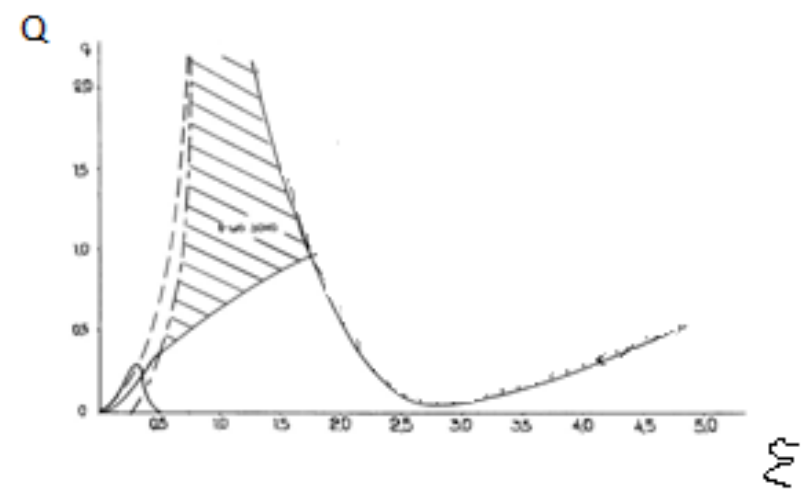

Fig. 9. Map of the stability of the vibration damping sieve for the implementation of the first stage of the stability of its work.

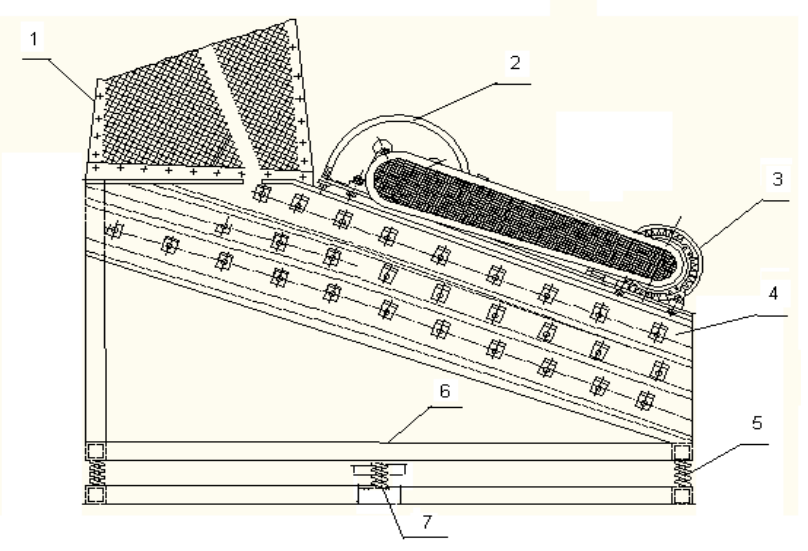

a

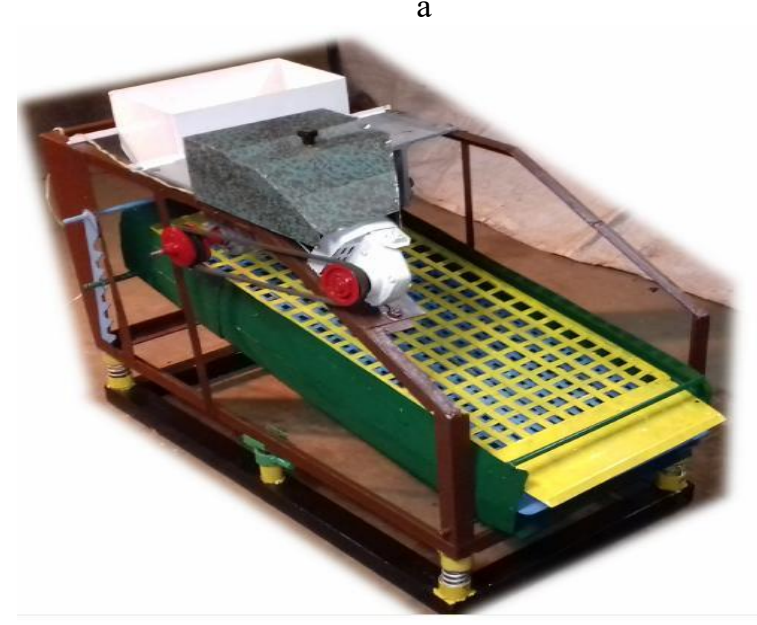

b

Fig. 10. Experimental vibration damping unit for sorting crushed stone: a - scheme, B - general appearance, 1 - bunker, 2 - box, 3 - drive, 4 - screen, 5 - bearings, 6 - frame, 7 - buffers.

Variable parameters in conducting experiments, in addition to the amplitude and frequency of oscillations, were the angle of inclination of the screen, the speed of the material on the sieve screen, the thickness of the material. 
The screen was picked up depending on the fractional composition of the gravel with the appropriate size of the apertures. In accordance with the research methodology, a series of experiments was conducted, the parameters of the sorting process were recorded by special sensors. Their values were fixed on the computer display and entered in the table.

The next stage of research was based on graphs and compared the results of performed experiments with the estimated values of the results of theoretical studies.

The process of sorting with two screen for distribution into small and large fractions is shown in Fig. 11.

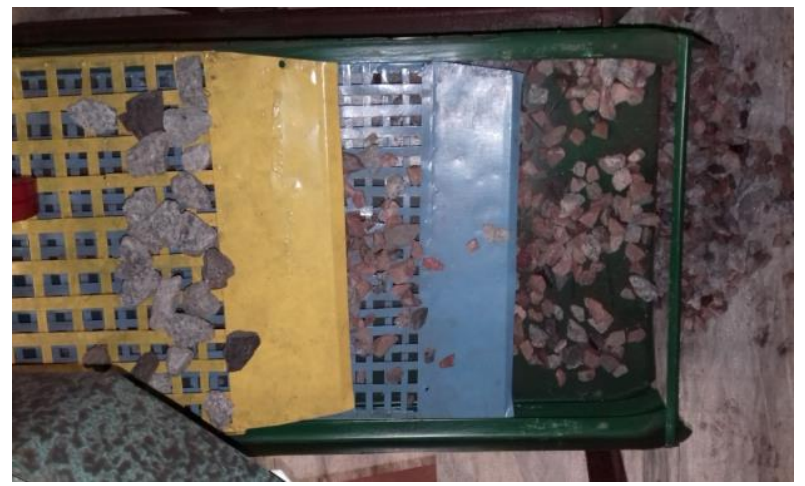

Fig. 11. The process of sorting rubble on two vibrogram vibrating screen.

Comparison among themselves the results of the experiments with the calculated values of theoretical studies have shown satisfactory in the trials, the difference in the values of the unknown parameters. For example, the difference between the amplitude of oscillations sieve, obtained in the experiments and the calculations amounted to $14 \%$ and power $-17 \%$. Fig. 12 shows an example of vibrogram vibrating amplitude changes that obtained in experiments and theoretical calculations performed.
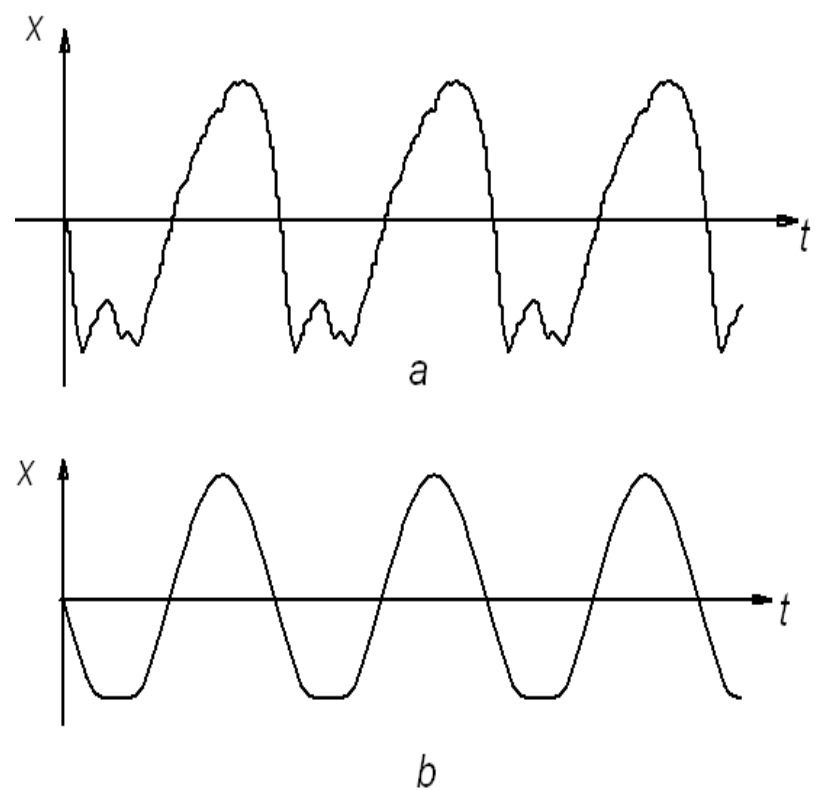

Fig. 12. Change in the amplitude of the oscillation of the screen, obtained in experiments $a$ and performed in the calculations $b$.
The proposed algorithm for calculating the dynamic "sieve - material" system involves the following implementation procedure.

The first block involves making decisions on the values of output parameters: the required performance, fractional composition of the material and its density, necessary for this sorting process amplitude and frequency of oscillations.

The second block includes the calculation: the fractional composition of the grinding products for the upper and lower screen of a two-sided sieve.

The size of the holes for the corresponding screen, screen area and its size (length and width), sorting efficiency.

Angle of inclination, structural and technical characteristics of the sieve (the mass of the sieve and the material to be sorted, the elasticity of the supports and the buffer, the static moment of mass unbalance and the engine power), criteria of stability of the vibration damping mode of operation.

The third block represents the verification of the obtained results: the numerical values of the amplitude and frequency of oscillation stability of the resonant vibration shock mode.

On the basis of the algorithm the method of engineering calculation of the parameters of the "sieve material" system is developed, the construction of the vibration damping crane is proposed, the novelty of which is confirmed by the patent for the utility model.

\section{Conclusions}

1. The performed review and analysis showed that improvement of the model of the system "vibration damping roller - sorting material" that adequately reflects the actual process of sorting is needed.

2. The working process of material sorting with the consistent movement of material particles in the field of harmonic and shock-vibrational action is investigated.

3. A calculation scheme is developed and the equations of the joint motion of the investigated system are obtained, the solutions of which are dimensionless parameters that serve as criteria for assessing the vibration-shock mode of sorting.

4. Determination of changes in boundaries of dimensionless parameters that reflect the steady-state operation of a shock-vibration sieve, implementing an efficient sorting process in a mode that is close to resonant. A map of stability was provided and the vibration shock mode was provided at the main resonance.

5. Experimental researches have been carried out to determine the influence of the amplitude and frequency of oscillations with different angles of the crater box inclination on the course of the crushing process. Comparison among the results of the performed experiments with the estimated values of the results of theoretical studies showed satisfactory, in the framework of the conducted research, the discrepancy in the values of the desired parameters.

6. The algorithm is proposed and the method of calculating the parameters of the "sieve-material" system 
is developed, the construction of the vibration damping crane is proposed, the novelty of which is confirmed by the patent for the utility model.

\section{References}

1. Weissberg L. A. (2006). Designing and calculating of vibrating screens. Moscow: Nedra, 144.

2. Weissberg L. A. (2005). Screening Surfaces. Structures, materials, experience of application. St.Petersburg: ALL WEEKS. 250.

3. Nazarenko I. I. (2009). Machines for the production of building materials: a textbook. Kyiv. KNUBA. 544.

4. T-H Kim, I. Maruta, T. Sugie, (2010). A Simple and Effective Constrained Particle Swarm Optimization and its Application to Engineering Design Problems, Journal of Mechanical Engineering, Vol. 224, No 2, 389-400.

5. Bolotnik N. N. (2006). Dynamics of controlled motions of vibrational systems. Izvestiya RAN. Theory and control systems. 15. 157-167.

6. Pelevin A. E. (2011). Probability of passage of particles through a sieve and the process of segregation on a vibrating screen. Izvestiya high schools. Mountain journals. No. 1. 119-129.

7. Tkachuk N. A., Grabovsky A. V., Tkachuk N. N., Kostenko Yu. V., Artemov I. V. (2011). Numerical modeling of dynamic processes in vibro-impact systems. "Bulletin of the NTU "KPI". That's it. issue: Mathematical modeling in technology and technologies, № 42, 179-187.

8. Volkov E. B., Glukhikh I. A., Lyaptsev S. A. (2013). Theoretical analysis of the technological parameters of vibrating screens. Modern problems of science and education. № 6 (application "Technical sciences"). 12.

9. Features of high-quality screening (2007). [Electronic resource]. Mining industry. No. 6. P. 42-43. Access http://www.miningmedia.ru/en/article/gorobor/871osobennosti-vysokochastotnogo-grokhocheniya.

10. Panovko G. Ya. (2006). Dynamics of vibrational technological processes. Moscow: SIC "Regular and chaotic dynamics", Institute of Computer Research. 158.

11. Gerega I. I. (2005). Interaction of working load with a working body in shock-vibration machines. Problems of Strength. No. 4. 74-82.

12. Novokhatniy V., Kostenko S. (2014). Reliability of cooling circulating water supply systems. MOTROL. Commission of Motorization and Energetics in Agriculture. Vol. 16. No. 6, 77-84.

13. Chekmenev $V$. (2015). The optimization work of diesels of agricultural machinery and tractors. MOTROL. Commission of Motorization and Energy in Agriculture. Vol. 17, No. 1, 5-10.

14. Nazarenko I. I. (2010). Applied problems of the theory of vibration systems. Tutorial. (2nd edition). Kyiv. Publishing House "Word". 440.

15. Orishchenko S. V. (2008). Investigation of the influence of mass of material on the sieve of a vibrating screen. Engineering of construction. № 21. 157-160.
16. Nazarenko I. I. (2009). Modeling of the process of motion of the material on the screen. Engineering of Construction. No. 22. 81-84.

17. Matsyuk B. V. (2014). Estimation of the structural elements of the vibrating screen. The theory and practice of construction. No. 13. 26-29.

18. Matsyuk B.V. (2015). Increasing the efficiency of working parameters of vibration separation of building materials. Engineering of construction. No. 34. 34-37.

19. Arsentyev V. A, Blekhman I. I, Blekhman L. I., Weissberg L. A., Ivanov K. S., Krivtsov A. M. (2010). Methods of the dynamics of particles and discrete elements as an instrument for studying and optimizing the process of processing natural and man-made materials. Enrichment of ores. № 1. 30-35.

20. Volkov E. B. Lyaptsev S. A. (2013). Influence of the slope angle of the working surface of the vibrating screen on the efficiency of the screening. Modern problems of science and education. № 4. 45 .

21. Falko O. L. (2014). Separation of bulk materials into three fractions with their vibrational displacement. 5 . $15-18$.

\section{Список літератури}

1. Вайсберг Л. А. Проектування та розрахунок вібраційних екранів. Москва: Недра, 2006. 144 с.

2. Вайсберг Л. А. Екранні поверхні. Структури, матеріали, досвід застосування, Санкт-Петербург: Тижневик. 2005. 250 с.

3. Назаренко I. I. Машини для виготовлення будівельних матеріалів: підручник. Київ. КНУБА. 2009. 544 c.

4. T-H Kim, I. Maruta, T. Sugie. A Simple and Effective Constrained Particle Swarm Optimization and its Application to Engineering Design Problems, Journal of Mechanical Engineering, 2010. Vol. 224, No 2, P. 389-400.

5. Болотник Н. Н. Динаміка керованих рухів коливальних систем. Известия РАН. Теорія та системи управління. 15. 2006. С. 157167.

6. Пелевін $A . \quad \epsilon$. Вірогідність проходження частинок через сито та процес сегрегації на віброситі. Вищі вузи. Гірські журнали. 2011. № 1. С. 119129.

7. Ткачук Н. А., Грабовський А. В., Ткачук Н. Н., Костенко Ю. В., Артемов І. В. Числове моделювання динамічних процесів у віброударних системах. «Вісник НТУ «КПІ» Математичне моделювання в техніці та технологіях, 2011. № 42, С. 179-187.

8. Волков С. Б., Глухих I. А., Ляпцев С. А. Теоретичний аналіз технологічних параметрів вібраційних екранів. Сучасні проблеми науки та освіти. № 6 (додаток «Технічні науки»). 2013. 12.

9. Features of high-quality screening (2007). [Electronic resource] // Mining industry. No. 6. P. 42-43. Access mode: http://www.miningmedia.ru/en/article/gorobor/871osobennosti-vysokochastotnogo-grokhocheniya.

10. Пановко $Г$. Я. Динаміка коливальних технологічних процесів. Москва: СІК "Регулярна i хаотична динаміка", Інститут комп'ютерних досліджень. 2006. 158 с. 
11. Герега I. I. Взаємодія робочого навантаження 3 робочим тілом у ударно-вібраційних машинах. Проблеми сили. 2005. № 4. С. 74-82.

12. Novokhatniy $V$., Kostenko $S$. Reliability of cooling circulating water supply systems. MOTROL. Commission of Motorization and Energetics in Agriculture. 2014. Vol. 16. No. 6, P. 77-84.

13. Chekmenev $V$. The optimization work of diesels of agricultural machinery and tractors. MOTROL. Commission of Motorization and Energy in Agriculture. 2015. Vol. 17, No. 1, P. 5-10.

15. Оріменко C. В. Дослідження впливу маси матеріалу на сито вібросити. Техніка будівництва. 2008. № 21. C. 157-160.

16. Назаренко I. I. Моделювання процесу руху матеріалу на екрані. Техніка будівництва. 2009. № 22. C. $81-84$.

17. Мацюк Б. В. Оцінка структурних елементів вібросита. Теорія та практика будівництва. 2014. № 13. С. 26-29.

18. Мацюк Б. B. Підвищення ефективності робочих параметрів вібраційного поділу будівельних матеріалів. Техніка будівництва. 2015. № 34. С. 34-37.

19. Арсентьєв В. А., Блехман I. І., Блехман Л. І., Вайсберг Л. А., Іванов К. С., Кривцов А. М. Методи динаміки частинок i дискретних елементів як інструмент вивчення та оптимізації процесу обробки природних і техногенних матеріалів. Збагачення руд. 2010. № 1. С. 30-35.

20. Волков Е. Б. Ляпцеев С. А. Вплив кута нахилу робочої поверхні вібросити на ефективність екранування. Сучасні проблеми науки та освіти. 2013. № 4.45 c.

21. Фалько О. Л. Поділ сипучих матеріалів на три фракції 3 їх коливальним переміщенням. 2014. C. $15-18$.

\section{ДОСЛІДЖЕННЯ РОБОЧИХ ПРОЦЕСІВ СОРТУВАННЯ МАТЕРІАЛІВ ТА ДИНАМІЧНИХ ПАРАМЕТРІВ ВІБРАЦІЙНОГО ЕКРАНУ Б. В. Матсюк, С. В. Орищенко}

Анотація. Обгрунтованими передумовами та припущеннями при вивченні робочого процесу сортування будівельного матеріалу є обрана модель системи «віброгасильний ролик - сортувальний матеріал», що адекватно відображає фактичний процес сортування. Досліджуються фактори впливу на процес сортування матеріалу: гранулометричний склад та форма зерна фракції, щільність та вологість сировини, товщина шару матеріалу на екрані, швидкість зерен на екрані. Що стосується сита, то такі фактори: амплітуда та частота коливань, кут нахилу коробки, форма та розміри отворів сита, розмір поверхні, сортування та режим роботи сита, який реалізує ці параметри. Було встановлено, що збільшення довжини збільшує ймовірність проходження частинок через екран, збільшуючи ефективність сортування. Досліджено робочий процес сортування матеріалу з послідовним переміщенням частинок матеріалу в області гармонійної, а потім і ударно-коливальної дії. Визначено оцінку процесу сортування та параметрів цього процесу. Доведено, що використання загальних гармонічних та ударних режимів руху $\epsilon$ ефективним. Саме ця гіпотеза $\epsilon$ основою цього дослідження. Надійність напрямку обумовлена тим, що при здійсненні режиму сортування вібраційного демпфування сильний вплив на частинки матеріалу значно збільшується. Як результат - можливість самоочищення тих отворів, в яких застрягли матеріальні частинки, та досягається підвищення ефективності та продуктивності сита. Розроблена схема проектування та отримані рівняння спільного руху досліджуваної системи. Розв'язання рівнянь визначається безрозмірними параметрами, які слугують критеріями оцінки режиму сортування вібраційного шоку. Визначено зміни меж безрозмірних параметрів, які відображають стабільну роботу ударно-вібраційного сита, реалізуючи ефективний процес сортування в режимі, близькому до резонансного. Була надана карта стійкості та забезпечено режим вібраційного удару на головному резонансі. Проводились експериментальні дослідження ефективності реалізації спільного віброударного режиму сортування на новоствореній установці. Порівняння параметрів, отриманих теоретичним та експериментальним шляхом, підтвердило надійність припущень та припущень, прийнятих у дослідженні. Розроблено алгоритм розрахунку системи «сито - матеріал», запропонована конструкція крана віброгасіння, новизна якого підтверджена патентом на корисну модель.

Ключові слова: дослідження, робота, процес, сортування, матеріал, параметр, вібраційний екран.

\section{ИССЛЕДОВАНИЕ РАБОЧИХ ПРОЦЕССОВ СОРТИРОВКИ МАТЕРИАЛОВ И ДИНАМИЧЕСКИХ ПАРАМЕТРОВ ВИБРАЦИИ ЭКРАНА}

Б. В. Матсюк, С. В. Орищенко

Аннотация. Обоснованными предпосылками и допущениями при изучении рабочего процесса сортировки строительного материала является выбранная модель системы «виброгасительный ролик сортировочный материал», что адекватно отражает фактический процесс сортировки. Исследуются факторы влияния на процесс сортировки материала: гранулометрический состав и форма зерна фракции, плотность и влажность сырья, толщина слоя материала на экране, скорость зерен на экране. Что касается сита, то такие факторы: амплитуда и частота колебаний, угол наклона коробки, форма и размеры отверстий сита, размер поверхности, сортировки и режим работы сита, который реализует эти параметры. Было установлено, что увеличение длины увеличивает вероятность прохождения частиц через экран, увеличивая эффективность сортировки. Исследован рабочий процесс сортировки материала с последовательным перемещением частиц материала в области гармоничной, а затем и ударноколебательного действия. Определена оценка процесса сортировки и параметров этого процесса. Доказано, что использование общих гармонических и ударных режимов движения является эффективным. Именно эта гипотеза является основой данного 
исследования. Надежность направления обусловлена тем, что при осуществлении режима сортировки вибрационного демпфирования сильное влияние на частицы материала значительно увеличивается. Как результат возможность самоочистки тех проемов, в которых застряли материальные частицы, и достигается повышение эффективности и производительности сита. Разработана схема проектирования и полученные уравнения совместного движения исследуемой системы. Решение уравнений определяется безразмерными параметрами, которые служат критериями оценки режима сортировки вибрационного шока. Определены изменения границ безразмерных параметров, которые отражают стабильную работу ударно-вибрационного сита, реализуя эффективный процесс сортировки в режиме, близком к резонансному. Была предоставлена карта устойчивости и обеспечен режим вибрационного удара на главном резонансе. Проводились экспериментальные исследования эффективности реализации совместного вибро-ударного режима сортировки на созданной установке. Сравнение параметров, полученных теоретическим и экспериментальным путем, подтвердило надежность допущений и предположений, принятых в исследовании. Разработан алгоритм расчета системы «сито-материал», предложенная конструкция крана виброгашения, новизна которого подтверждена патентом на полезную модель.

Ключевые слова: исследование, работа, процесс, сортировка, материал, параметр, вибрационный экран.

Б. В. Матсюк ORCID 0000-0003-0636-4748.

С. В. Орищенко ORCID 0000-0001-7556-7763. 
